\title{
Die boodskap van die kruis as die middelpunt van Pauliniese teologie
}

\author{
Zumstein, Jean \\ Universiteit van die Vrystaat \\ zumstein.jean@access.uzh.ch
}

\begin{abstract}
Within early Christianity Paul of Tarsus is a representative of the kerygmatic tradition in which Christ's death and resurrection are viewed as the central event of salvation. In this sense he adopts the traditional interpretations of Jesus' death. However, he also reverses traditional hermeneutics by suggesting a new reading of Christ's death, called 'theology of the cross'. This innovative interpretation considers the cross as the exclusive locus of God's revelation, his judgment and salvation. This way of interpreting forms the structural backbone of Pauline theology.
\end{abstract}

Key words

Cross; theology of Paul; theology of the cross; revelation

In die hedendaagse eksegetiese gesprek ${ }^{1}$ is die posisie en belangrikheid van die Pauliniese literatuur binne die geskiedenis van die vroeë Christendom steeds omstrede. Een vraag is veral die fokus van die debat: Watter beginsel struktureer Paulus se denke? Is dit moontlik om 'n teologiese koherensie in Paulus se briewe te vind ten spyte van die diversiteit van voorveronderstelde omstandighede en vraagstukke wat aangepak word? Met ander woorde, is daar 'n sentrale teologiese verklaring wat rigting gee aan die apostel se teologiese werk en struktuur aan sy teologiese besinning verleen? Indien wel, wat is die fundamentele verklaring wat as die beginpunt van die Pauliniese diskoers gebruik kan word?

1 Vgl. bv. Conzelmann (1997:164-112); Hübner (1987:2649-2840); Merk (1988:1-81); Rengstorf (1982:1-97); Stuhlmacher (1992:234-252). 


\section{Paulus en die tradisionele interpretasies van Jesus se dood}

\subsection{Paulus as die erfgenaam van die kerugmatiese teologie}

Die leser van Paulus se brief sou geïrriteer kon raak deur die manier waarop die apostel Christus uitbeeld. Waar die Evangelies die klem hoofsaaklik laat val op Jesus se openbare bediening, sy lering, wonderwerke en botsings met die godsdienstige owerhede, ignoreer Paulus alle tradisies wat die lewe en werke van die Nasarener beskryf. Sy aandag word geheel en al in beslag geneem deur een enkele gebeure - Jesus se dood aan die kruis en sy opstanding. ${ }^{2}$ Is dit daaraan toe te skryf dat die apostel niks verder omtrent Jesus se lewe geweet het nie en dat sy kennis beperk was tot die belewenis van sy visioen op die pad na Damaskus? Hierdie verduideliking is nouliks oortuigend omdat Paulus in werklikheid bekend was met die tradisies oor die lewe van die aardse Jesus wat in omloop was. $\mathrm{Na}$ alle waarskynlikheid het Paulus meer as genoeg gehoor aangaande Jesus, sy prediking en sy wonderdade - as 'n vervolger van die kerk wat Joodse Christene oor hulle oortuigings en hulle houding jeens die Wet ondervra het, as 'n passievolle gespreksgenoot van Petrus, die dissipel van Jesus, of as jare lange lid van die kerk van Antiochie.. ${ }^{3}$ Tog maak hy feitlik nooit melding van hierdie deel van die tradisie nie om sy interpretasie van die Christelike geloof te ontwikkel. Hoe kan ons hierdie verbasende stilte oor Christus se lewe of die besondere belangstelling in sy dood verklaar?

Met hierdie teologiese besluit ontgin Paulus nie nuwe terrein nie. Hy volg die tradisie van sy groep. ${ }^{4}$ Dit word bewys deur die aanhaling wat die lang hoofstuk oor die opstanding in 1 Korintiërs 15:3-5 inlei": "Want die wesenlike wat ek ontvang en ook aan julle oorgelewer het, is: Christus het vir ons sondes gesterf volgens die Skrifte, Hy is begrawe en op die derde dag opgewek volgens die Skrifte, en Hy het aan Sefas verskyn, en toe aan

2 Oor die beginpunt van Pauliniese teologie, vgl. Becker (1989:395-402); Bultmann (1984:188-192); Bornkamm (1969:121-131); Conzelmann (1997:171-172); Dunn (1998:1-26); Goppelt (1976:362-390); Lohse (1996:241-249); Sanders (1995:98-101); Stendhal (1978); Stuhlmacher (1992:234-252).

3 Oor die lewe van Paulus van Tarsus voor sy bekering tot die Christelike geloof, vgl. Becker (1989:60-73); Bornkamm 1969:27-36); Hengel (1991:177-291). Vgl. ook Dunn (1998:182-206).

4 Oor die verhouding tussen Paulus en die kerugmatiese tradisie, vgl. Conzelmann (1997:178-181); Zumstein, J (2000:93-108).

5 Vir die huidige stand van die bespreking oor 1 Kor. 15:3-5 sien Schrage ( 2001:10-52). 
die twaalf." Hierdie stellig ou belydenis, waarop die apostel se argument gegrond is, is slegs een voorbeeld; soortgelyke bewoordings kom oral in sy briewe voor. ${ }^{7}$ Die evangelie wat Paulus in Antiochië leer ken het, bestaan uit die verkondiging van die dood en opstanding van Christus as 'n reddingsgebeure. Deur die Christologiese geloof in die rigting van die kruis en Pase te stuur, het Paulus bloot die oortuiging van 'n bepaalde teologiese stroming in die vroeë Christelike beweging aanvaar en dit bygewerk - die sogenaamde kerugmatiese stroming. Hoewel die apostel se geloof deur 'n ekstatiese belewenis aan die gang gesit is, is sy teologie gegrond op die aanvaarding van 'n belydenis wat tussen die jare 30 en 40 in Antiochië aan die Orontes algemeen bekend was. ${ }^{8}$ Vir die skepping van die Pauliniese teologie word 'n teologiese besluit van die grootste belang geneem: Die nuwe geloof konstitueer sigself vanuit die kruis. Hier lê sy eksklusiewe punt van oriëntasie.

\subsection{Die interpretasies van Jesus se dood}

Met die aanname van die belydenis van die gemeenskappe binne die kerugmatiese stroming, aanvaar Paulus tegelykertyd ook 'n reeks interpretasies van Jesus se dood. Met hierdie interpretasies het die eerste Christene probeer om betekenis te gee aan die skandelike dood van hulle Here, aangesien hulle verplig gevoel het om aan te toon dat Jesus se teregstelling nié 'n absurde voorval, ook nie 'n regsdwaling, en ook nie 'n welverdiende doodstraf was wat op die oortreding van die wet gevolg het nie, maar eerder 'n produktiewe gebeurtenis wat in sigself lewe en 'n toekoms verteenwoordig het. ${ }^{9}$

Die eerste interpretasie van Jesus se dood was klaarblyklik die belydenis van sy opstanding. ${ }^{10}$ Deur te verkondig dat die gekruisigde Jesus lewend was en dat Hy aan hulle verskyn het, het Jesus se dissipels gewys dat God nie sy gesant aan onherroeplike uitwissing oorgegee het nie, inteendeel, dat Hy Homself in die gekruisigde Jesus herken het en Hom met sy lot

6 Aanhaling uit Nuwe Testament en Psalms: 'n Direkte vertaling.

7 Vgl. Conzelmann (1974:106-119); Strecker (1996:69-84); Wengst (1972).

8 Vgl. Küster (1987:191-215); Stuhlmacher (1992:179-196).

9 Oor die interpretasies van Jesus se dood in die ontwikkelende Christelike geloof, vgl. Barth (1992); Conzelmann et aI. (1967); idem (1997:49-57).

10 Sien in hierdie konteks die verklarende opmerkings van Senft (1990:215-218). 
vereenselwig het, en so Hom geroep het om aan sy sy te lewe. Gevolglik was die kruis nie langer die plek van God se afwesigheid en verlatenheid nie, maar die ruimte van sy enigmatiese teenwoordigheid en sy paradoksale openbaring. Vanselfsprekend onderskryf Paulus hierdie oortuiging soos bo alle twyfel bewys word deur die visioen van Damaskus. Indien losgemaak van die opstanding is die kruis vir hom 'n sinlose tragedie. Omgekeerd egter, die opstanding wat daarop aanspraak maak dat dit losstaan van die kruis of belangriker wil wees as die kruis is 'n misleidende interpretasie van die verhaal van Jesus. ${ }^{11}$

Bo en behalwe die Paas-belydenis, het die eerste Christene, by wie Paulus sy geloof geleer en geleef het, baie verskillende konsepte gebruik om uitdrukking te gee aan die betekenis van Jesus se dood aan die kruis deur gebruik te maak van die rykdom van die Skriftradisie of die gewoontes en gebruike van die Grieks-Romeinse kultuur. Die gevolg van hierdie interpretasiewerk is ryk en divers. Vyf konseptuele velde is toegepas: ${ }^{12}$ Jesus se dood is verstaan as die lokus van versoening wat God die mensdom aanbied (2 Kor. 5:14-6:2; Rom. 5:1-11), of as 'n gebeurtenis van bevryding: Aan die kruis laat staan die mens slawerny en bereik vryheid - hy word van sonde verlos (Rom. 5:21; 6:23; 7:7 e.v.), van die Wet (Gal. 3:23-25; 4:1-3) en van die dood (1 Kor. 15:25, 54-57; Rom. 5:14). Of Jesus se dood het die betekenis van 'n plaasvervangende daad verkry: Jesus sterf in die plek van sy broers en susters sodat hulle kan lewe (1 Kor. 15:22; 2 Kor. 15:5; Rom. 5:18 e.v.) In 'n ander interpretasie het Jesus se dood die funksie van 'n soenoffer verkry (Rom. 3:25-26; 5:9; 8:3) - die offer wis die verwoestende gevolge van sonde uit. Laastens, die betekenis van Jesus se dood is verklaar deur middel van die terminologie van die regverdigmaking: God bly getrou aan sy verbond. ${ }^{13}$

11 Teenoor Schrage (1997:25-38).

12 Vgl. Becker (1989:432-437); Dunn (1998:207-233); Käsemann (1969:72-82).

13 'n Misverstand moet hier vermy word. Paulus het reeds die regverdigmakingterminologie in die tradisie van sy kerk gevind. Aan die een kant is dit verwant aan die tema van 'n verhoor, aan die ander kant aan dié van die doop. (Met betrekking tot die wortels van die konseptuele veld regverdig/regverdigmaking vgl. J. Becker 1989:294-304). Wat Paulus op teologiese terrein bereik het, is die toepassing van die sprake van regverdigmaking op die mens. God bly getrou aan sy verbond deur die mens regverdig

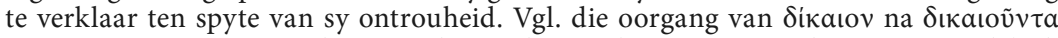
in Rom. 3:25 e.v., wat as die apostel se teologiese kommentaar gelees moet word (vgl. Käsemann (1973:92); Stuhlmacher (1992:298). 
Die feit dat Paulus in sy briewe hierdie verskillende teologiese interpretasies vermeld van wat aan die kruis gebeur het, wat almal die soteriologiese belangrikheid van Jesus se dood beklemtoon, toon dat hy daarmee saamstem. Een belangrike saak moet egter in ag geneem word: Hierdie verskillende semantiese velde word gebruik om die ramp van Jesus se dood aan die kruis te verklaar en betekenis daaraan te gee. Die kruis verg interpretasie: die ondenkbare moet bedink word, die onbegryplike moet begryp word, die onaanvaarbare moet aanvaar word. So daag Jesus se dood die godsdienstige gemeenskap uit om uitdrukking aan sy betekenis en skeppende krag te gee.

Kom ons neem die aangeleentheid in oënskou. Paulus neem drie elemente uit die kerugmatiese tradisie:

- Die kruis is die eksklusiewe spil waarom die Christologiese geloof draai.

- Die Paas-belydenis verkondig die kruis as die lokus van God se paradoksale openbaring.

- Jesus se dood op Golgota is van die grootste soteriologiese belang: Dit is die lokus van gelowiges se lewe en toekoms.

Paulus hou egter nie hier op nie. Hy ontwikkel 'n bepaalde interpretasie van Jesus se dood wat uitgedruk word in die "boodskap van die kruis" en wat paradigmaties in die sogenaamde "teologie van die kruis" ontwikkel word.

\section{Paulus, skepper van die teologie van die kruis}

\subsection{Die taal van die kruis}

'n Deeglike ontleding van Paulus se briewe lei tot 'n baie belangrike linguistiese bevinding: ${ }^{14}$ Telkens wanneer Paulus tradisionele formules en konsepte gebruik om Jesus se dood te beskryf, gebruik hy die werkwoord "om te sterf" (ả $\operatorname{\theta } \theta v \underline{n} \sigma \kappa \omega)$ en die selfstandige naamwoord "dood" (Өavátoc). Sodra hy egter begin om sy eie interpretasie van Jesus se dood te

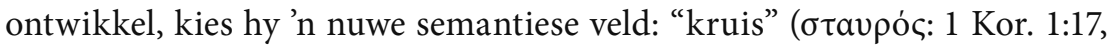

14 Vgl. Kuhn (2011:643-645); idem, (2011a:647-648); Vouga (2001:307-308). 


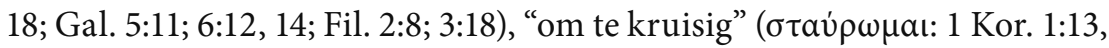
23; 2:2, 8; 2 Kor. 13:4; Gal. 3:1; 5:7, 4; 6:14), en "om gekruisig te wees saam

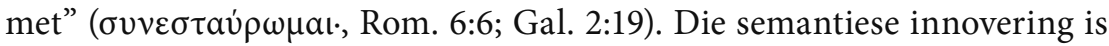
voor die hand liggend: Die terminologie van die kruis verwys nie langer na die instrument van marteling en die spesifieke wyse van teregstelling nie, maar bevat' $n$ metaforiese betekenis wat ondersoek moet word. ${ }^{15}$

Vyf opmerkings moet hierdie taak voorafgaan:

- Die konsep "teologie van die kruis" omvat nie al die interpretasies van Jesus se dood wat in Paulus se briewe voorkom nie; dit verwys slegs na daardie interpretasie wat deur die semantiek van die kruis gedomineer en gestruktureer word.

- Die semantiek van die kruis kom voor in die briewe aan die Korintiërs ( 1 en 2 Kor.) sowel as in die briewe aan die Galasiërs en Filippense. Hierdie bevinding is van belang aangesien dit toon dat hierdie semantiek in die Korintiese briewe voorkom wat bo alles handel oor die teenoorgesteldes wysheid/dwaasheid of krag/swakheid sowel as in die briewe aan die Galasiërs en die Filippense, wat fokus op die onderwerp van regverdigmaking. Die taal van die kruis is derhalwe 'n element wat oral in die Pauliniese briewe voorkom en hulle aan mekaar skakel.

- Die semantiek van die kruis is altyd gebonde aan 'n polemiese konteks. In die Korintiese briewe polemiseer Paulus aan die een kant teen faksies wat met spirituele fenomene besiel was (pneumatiese entoesiasme), terwyl hy in die briewe aan die Galasiërs en Filippense homself aan die ander kant verdedig teen Judaïserende sendelinge wat probeer het om weer 'n godsdienstigheid in te stel wat verklaar dat die besnydenis en nakoming van die Wet voorvereistes vir redding is (Nomisme).

- Die polemiese gedeeltes handel oor hierdie drie groot onderwerpe wysheid, Wet en die lewe in geloof. Uitermatige wysheid kulmineer in manifestasies van die Gees; die Wet lei tot 'n godsdienstigheid wat deur wettigheid en selfingenomendheid bepaal word; die lewe in geloof kom voor breekpunte te staan.

15 Vgl. bv. Becker (1989:217-218); Käsemann (1969:65); Schrage (1997:29-30). 
- Ten slotte moet daar op 'n beduidende weglating gewys word:

Christus se opstanding, hoewel dit geïmpliseer word, word nooit eksplisiet genoem nie.

Die belangrikheid van hierdie bevindings word in die volgende afdeling bespreek.

\subsection{Die hermeneutiese omkering}

In die gedeeltes wat die teologie van die kruis op 'n spesifiek Pauliniese wyse ontwikkel, speel Jesus se dood 'n totaal nuwe rol in die apostel se argumentasie. Terwyl Jesus se dood in die tradisionele of tradisioneel geïnspireerde bewoordings self in die fokus van aandag is en interpretasie vereis, lewer die kruis in die gedeeltes wat gekenmerk word deur die teologie van die kruis, die kriterium waarvolgens die hele werklikheid geïnterpreteer word. ${ }^{16}$ Voortaan het die boodskap van die kruis 'n hermeneutiese funksie. Dit interpreteer alle aspekte van die wêreld, die mens insluitend al sy lewensomstandighede en die besluite wat hy neem, en God in sy openbaring. Die hermeneutiese omkering is indrukwekkend: Die kruis is nie langer die voorwerp van interpretasie nie, maar die onderwerp. Dit bevat die potensialiteit van betekenis wat toelaat om die wêreld in sy waarheid te verklaar - uit 'n Pauliniese oogpunt, weliswaar. In hierdie sin is Luther se stelling "Crux probat omnia"17 die voorbeeld van 'n korrekte resepsie van die Pauliniese denke.

Kom ons gaan een stap verder: Paulus verklaar in 1 Korintiërs 1:18-2:5 die locus classicus van die teologie van die kruis: "Ek het besluit om by julle niks anders te weet nie as Jesus Christus, en Hom as gekruisigde" (2:2). ${ }^{18}$ Derhalwe is die boodskap van die kruis nie onder andere bloot 'n hermeneutiese beginsel nie. As die werklikheid eers een maal vanuit die kruis geïnterpreteer is, kan dit nie meer anders geïnterpreteer word nie, bv. vanuit die opstanding, vanuit die skeppingsleer of vanuit die leerstelling van God. Die boodskap van die kruis is die eerste en die laaste boodskap wat struktuur aan die hele teologiese sisteem gee. Christologie, antropologie, die konsep van geskiedenis, soteriologie, ekklesiologie,

16 Hierdie hermeneutiese omkering word veral beklemtoon deur Luz (1974:121-122).

17 WA V, 179, 37.

18 Aanhaling uit Nuwe Testament en Psalms: 'n Direkte vertaling 
pneumatologie, etiek, eskatologie - alles moet vanuit die kruis bedink word. Die eerste brief aan die Korintiërs verskaf die beste voorbeeld van hierdie herstrukturering van die teologiese sisteem. Nadat hy die boodskap van die kruis gevestig en bespreek het, beantwoord Paulus al die vrae en los al die probleme wat in Korinte voorkom op vanuit hierdie fundamentele kriterium van sy teologie. Elian Cuvillier toon die grondigheid van hierdie tese met betrekking tot 1 Korintiërs 13 aan. ${ }^{19}$ Weereens verteenwoordig Luther 'n belangrike hoofstuk binne die resepsiegeskiedenis van Pauliniese denke waar hy skryf: "CRUX sola est nostra Theologia". ${ }^{20}$

Tot dusver het ons egter nog nie melding gemaak van die mees kritieke en tegelykertyd mees ingrypende aspek van hierdie hermeneutiese besluit nie. Die konsep "teologie van die kruis" wys alreeds daarop dat'n teo-logie in die streng sin van die woord ter sprake is: Die enigste moontlike diskoers oor God begin vanuit die kruis, en hierdie stelling het twee betekenisse: Aan die een kant het God geen ander gesig benewens dié van die gekruisigde Jesus nie, en aan die ander kant open die kruis die moontlikheid om oor God te praat. Sonder die kruis is teologie blind; sonder teologie is die kruis doof.

Nou, indien die boodskap van die kruis die hermeneutiese beginsel is waarna die apostel verwys, ontstaan die volgende vraag: Tot watter interpretasie van die werklikheid lei dit?

Ons hipotese, hoofsaaklik gegrond op die werk van Käsemann, Luz en Becker $^{21}$, is soos volg: Die boodskap van die kruis is 'n totaal polemiese en deurslaggewende boodskap, wat radikale vrae stel aan die wêreld soos dit is en aan die mens in sy lewe. Dit gee aanleiding tot 'n krisis van sekerhede en waardes wat op hulle beurt aan die een kant lei tot die openbaring van God as gekruisigde, en aan die ander kant tot die aanbod van lewe wat nou moontlik gemaak word.

Die volgende afdelings sal aantoon hoe die "boodskap van die kruis" in die briewe aan die Korintiërs gelei het tot die begin en die ontwikkeling van die Pauliniese teologie van die kruis.

19 Cuvillier (2000:349-362).

20 WA V, 116, 32 e.v., met verwysing na Psalm 5, 12.

21 Käsemann (1969); Luz (1974). Becker (1989:218-229). 


\subsection{Die teologie van die kruis as die openbaring van oordeel}

Stellings wat deur die teologie van die kruis bepaal word, verskyn altyd binne'n polemiese konteks. Derhalwe vind ons in die brief aan die Romeine geen uitsprake wat na die teologie van die kruis verwys nie, aangesien dit' $n$ bekendstellings- en aanbevelingsbrief is. "Polemiese konteks" beteken dat Paulus probeer om 'n misleidende begrip van geloof aan die lig te bring wat hoogs populêr was in die gemeenskap aan wie hy skryf. Teologies gestel: Die apostel se bedoeling is om te toon hoe hopeloos die wêreld se situasie is en te beskryf hoe sleg dit is - dit is die hopelose situasie waaraan die ontvangers van die briewe gedreig het om toe te gee.

Watter hopelose situasie word hier bedoel? Watter wêreldsiening of eksistensiële ingesteldheid word radikaal deur die kruis bevraagteken? Waarom sal die wêreld verhoor word, volgens Paulus? In ooreenstemming met die algemene kerklike diskoers sou ons kan dink aan algemene "geloofloosheid", praktiese ateïsme ${ }^{22}$ of onsedelikheid. In hierdie sin sou die godsdienstige en morele tekortkominge van mense, in die besonder van die eerste Christene, die onderwerp van Paulus se kritiek kon wees. Dit is juis nie die geval nie. Paulus skryf: "Want daar staan geskryf: 'Ek sal die wysheid van die wyses tot niet maak en die insig van die verstandiges verwerp.' Waar is die wyse man, waar die skrifkenner, waar die redevoerder van hierdie wêreld? Het God dan nie die wysheid van hierdie wêreld dwaasheid laat word nie? Trouens, deur die wysheid van God het die wêreld Hom nie deur wysheid leer ken nie. God het verkies om hulle wat glo te verlos deur die dwaasheid van die verkondiging. Die Jode vra tekens en die Grieke soek wysheid. Ons, egter, verkondig 'n gekruisigde Christus. Vir die Jode is dit'n struikelblok en vir die nie-Jode 'n dwaasheid" (1 Kor. 1:19-23). ${ }^{23}$

Paulus se kritiek is derhalwe nie gerig teen die foute en tekortkominge nie, aangesien dit deel van elke mens se lewe is, maar teen die grootste prestasie waartoe ' $n$ menslike wese in staat is: die Grieke se strewe na wysheid en die Jode se soeke na God. Dit is kennis in sy mees grootse en gesaghebbende vorm wat bevraagteken word. Die mens in sy mees agtenswaardige intensie word beskuldig. Die lyk van die gekruisigde Jesus aan die kruis op Golgota

22 Oor praktiese ateïsme, vgl. Dubied (1982).

23 Aanhaling uit Nuwe Testament en Psalms: 'n Direkte Vertaling 
staan vir die mislukking van hierdie pogings en openbaar hulle dwaasheid, 'n dwaasheid wat niemand kan ontkom nie. In Paulus se oë simboliseer die Grieke en die Jode die ganse mensdom. As die wysheid van die Grieke en die vroomheid van die Jode lei tot die kruisiging van God se gesant, dan het menslike wysheid in dwaasheid verander, en kennis van God in onkunde.

Hoe is dit moontlik? Die wysheid van die Grieke ${ }^{24}$ bestaan in die poging om verskynsels in hulle totaliteit te rangskik en te verklaar, om 'n presiese plek aan elke element van die werklikheid toe te ken ten einde vir die wyse mens die sleutel te gee wat hom die wêreld sal laat verstaan waarin hy lewe. Selfs god vind sy plek in hierdie sisteem; hy is die oorsprong sowel as die einddoel daarvan. Die Jode se soeke na tekens is deel van 'n lang godsdienstige tradisie. Die God van die Jode is nie primêr waarneembaar in die kosmiese orde nie, maar in die geskiedenis. Deur middel van sy soewereine ingryping, sy kragtige dade en sy gesante, openbaar die God van Abraham, Isak en Jakob Hom in die geskiedenis; en aangesien die Jood weet wie God is, dink hy dat hy in staat is om God se teenwoordigheid in die wêreld raak te sien en te identifiseer. In die Griekse filosofie sowel as in die Joodse godsdienstigheid maak die mens daarop aanspraak dat hy God kan identifiseer. ${ }^{25}$ Maar deur dit te doen, hou God op om God te wees en is die mens nie langer die een wat alles van God verwag nie. Die liggaam van die gekruisigde Jesus is ' $n$ dwaasheid wat nie in enige rasionele sisteem geïntegreer kan word wat probeer om die werklikheid in sy geheel te verklaar nie. Netso is die liggaam van die gekruisigde Jesus 'n skande wat alle tradisionele opvattings van die godsdienstiges omtrent God tot 'n absurditeit reduseer. Die kruis is die rotswand waarteen die Grieke se wysheid en die Jode se godsdienstigheid hulle te pletter loop.

Kom die lede van die Pauliniese gemeenskap ongeskonde van hierdie radikale krisis van kennis af wat deur die kruis aan die gang gesit is? Het hulle die kruis oorkom? Paulus se antwoord is kort en saaklik. Die spirituele entoesiasme wat Korinte aangegryp het, die aanspraak van die entoesiaste

24 Oor die Griekse konsep van die wêreld vgl. bv. Bultmann (1949:132-148).

25 Vgl. bv. Conzelmann (1969:62), wat skryf: "Damit etablieren sie sich als Instanz, die über Gott urteilt. Dadurch ist ihr Verhalten, 'weltlich'. Sie muten Gott zu, sich ihren Kriterien zu unterwerfen." (Daardeur stel hulle hulself op as 'n gesag wat God oordeel. Dit maak hulle optrede "wêreldlik". Hulle verwag dat God aan hulle kriteria moet oorgee). In dieselfde rigting: Schrage (2001:191). 
dat hulle oor kennis en die Gees beskik, toon slegs die dwaasheid van die Grieke se soeke na wysheid in 'n ander gedaante. ${ }^{26}$ Die Korintiërs begin ook om die werklikheid te sistematiseer en 'n vaste plek aan God toe te ken. Hulle wil ook God by hulle idees laat aanpas. Hierdie spirituele okkupasie van God, hierdie aanspraak op die vermoë om die goddelike realiteit te domineer, hierdie onkunde aangaande die historisiteit van lewe in geloof dit alles toon nie minder dwaasheid en verlorenheid nie.

Die boodskap van die kruis plaas die wêreld in'n krisis. Dit spreek'n bepaalde oordeel uit oor die mensdom en die waardes wat dit verteenwoordig. Die mens se aanspraak om God tot sy beskikking te hê en God in sy eie persepsie van die werklikheid te integreer, en om God aan die mens se eie standaarde te meet - dit alles is eintlik'n uitdrukking van verlorenheid en wysheid wat in dwaasheid verander het. In hierdie sin verteenwoordig die boodskap van die kruis die meedoënlose blootlê van die mens se afdwalings en sy wil tot mag, en dit heel eerste in die kerk self.

\subsection{Die teologie van die kruis as God se openbaring}

Hierdie meedoënlose veroordeling van die mens se dwaasheid, hierdie krisis van kennis baan die weg vir die goddelike openbaring, vir die boodskap van die kruis, d.w.s. die prediking van die gekruisigde Christus as 'n uitdrukking van God se wysheid en mag (1 Kor. 1:24); dit verdoem al die mens se idees oor God tot mislukking. God laat Homself nie gelykstel aan wat mense oor Hom sê nie, Hy gee nie toe aan die mens se idees en wense nie, en Hy pas nie in die mens se filosofiese konstruksie nie. God is anders. Hy is heeltemal vry, en Hy maak Homself herkenbaar en weer herkenbaar waar niemand Hom verwag nie - aan die kruis van iemand wat doodgemartel is.

Tog is die boodskap van die kruis nie 'n absurde stelling wat die gedagtes provokeer bloot ter wille van provokasie nie; hierdie boodskap is eerder die uitdrukking van 'n fundamentele teologiese besinning: Slegs in die mate dat God nie die produk van menslike projeksies is nie, ook nie die ondubbelsinnige resultaat van bedrewe argumentering nie, slegs in die mate dat God Homself kwalitatief van die wêreld en sy omstandighede

26 Oor die verhouding tussen die "wysheid van die Grieke" en die Korintiese entoesiasme vgl. Weder, (1981:125-137). 
onderskei, is God werklik God. God is God slegs in sy andersheid. ${ }^{27}$ Positief gestel: As 'n teëhanger van die wêreld, is God die skepper van die wêreld (vgl. Rom. 1:18 e.v.).

Dus, volgens Paulus, impliseer God se openbaring 'n omkering van waardes. Hy skryf: "Maar die dwaashede van die wêreld het God uitgekies om die wyses te beskaam; en wat swak is by die wêreld, het God uitverkies om wat sterk is, te beskaam, en die swakhede van die wêreld het God uitgekies om die sterkes te beskaam, en die onbelangrike en veragtelike dinge van die wêreld het God uitgekies - dit wat niks is, om wat wél iets is, tot niet te maak, sodat geen mens voor God kan roem nie" (1 Kor. 27-29). Daar is 'n inherente paradoks in die boodskap van die kruis. ${ }^{28}$ Dit verklaar dat God Hom nie manifesteer in krag nie, maar in swakheid; nie in dinge wat waardevol is in die oë van die wêreld nie, maar in dinge wat verag word; nie in 'n oorvloed van lewe nie, maar onder die masker van die dood. Hierdie paradoksale stelling mag egter nie uit sy konteks gehaal word nie. God openbaar Homself op hierdie manier omdat die mens Hom nie in sy wysheid erken het nie en om die mens se dwaasheid aan die lig te bring. 'n Omkering van waardes en 'n krisis van sekerhede in hierdie wêreld is onlosmaaklik verbind.

Dit is egter noodsaaklik om nie 'n nuwe stelsel tot stand te bring waarin God Homself sou manifesteer strydig met daardie waardes wat die Jode en die Grieke met die goddelike geassosieer het nie. ${ }^{29}$ So 'n argumentering sou weereens ontken dat God anders is; dit sou nie daarin slaag om sy vryheid te realiseer nie en sou van Hom besit probeer neem - kortom, dit sou swig voor die gevaar van kontra-afhanklikheid. ${ }^{30}$ Dit sou as't ware God se versaking van alle wysheid, krag en die ganse lewe impliseer. In hierdie opsig gaan dié gedeelte ondubbelsinnig voort. Paulus skryf verder: "Deur Hom [God] is julle in Christus Jesus, wat vir ons die wysheid geword het wat van God kom: regverdiging sowel as heiliging en bevryding" (1 Kor.

27 Die stelling oor God wat anders is, beteken nie dat God Hom beslis onttrek van menslike kennis sodat slegs 'n negatiewe teologie daarna moontlik sou wees nie. Die ontdekking dat God anders is, vind plaas in 'n daad van openbaring, aan die kruis!

28 Die paradoks bestaan uit die boodskap van die kruis wat kenmerke aan God toeken wat strydig met Hom is (dood, swakheid, dwaasheid, ens.).

29 Op die punt om voor hierdie gevaar te swig is: Becker (1989:227), en Schrage (1991:189).

30 Oor die totaliteit van hierdie probleem, vgl. Bultmann (1965:117-132). 
1:30). Die God van die kruis is 'n God wat tot lewe roep wat nie bestaan nie, soos daar in Romeine 4:17 geskryf staan: "God ... wat die dooies lewend mak en dit wat nog nie bestaan nie, tot bestaan roep."

\subsection{Die teologie van die kruis as die openbaring van redding}

Die boodskap van die kruis is 'n protes teen en 'n radikale kritiek op die mens en die wêreld se vyandigheid jeens God; dit is egter in dieselfde mate heilsaam. Die teëhanger van oordeel is genade. Uit contra nos kom pro nobis na vore. ${ }^{31}$ In die volgende gedeelte is dit nodig om na hierdie derde aspek te kyk.

Om in hierdie saak reg aan Paulus te laat geskied, moet ons eers die linguistiese vorm van die boodskap van die kruis vasstel - dit is in die performatiewe vorm. ${ }^{32}$ Dit beteken dat die boodskap van die kruis nie 'n leerstelling oor God en redding is nie, maar 'n uiting is wat laat gebeur waaroor dit praat. Oordeel en genade sal gebeur met die persoon aan wie die boodskap van die kruis gepredik word. Paulus wys uitdruklik op

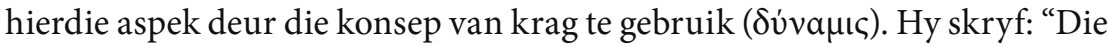
boodskap van die kruis is immers dwaasheid vir diegene wat verlore gaan, maar vir ons wat verlos word, is dit die krag van God" (1 Kor. 1:18). Die koppeling van die boodskap van die kruis met God se krag openbaar die soteriologiese betekenis daarvan, omdat dit as goddelike krag verandering moontlik maak, 'n verandering wat op lewe gerig is.

Van watter tipe verandering praat ons? Genade verwys eerstens na die kritieke dimensie van die kruis. Die boodskap van die kruis is 'n verligtende boodskap. Dit skep die moontlikheid om die misleidende illusies van die menslike lewe te identifiseer, om weg te bly van valse wysheid en godsdienstigheid, en om drome oor outonomie en almagtigheid te verdryf. Dit bestempel die poging om redding op jou eie deur middel van verdienstelike werke te verkry as verkeerd. Die boodskap van die kruis ontbloot die mens voor God. Dit herinner die mens aan sy broosheid en afhanklikheid. In Paulus se woorde: Dit neem vir seker die mens se aanspraak weg om homself te prys en die meester van sy lewe te wees. In hierdie opsig is die kruis 'n breekpunt: Die gelowige laat vaar 'n begrip van

31 'n Aspek wat duidelik beklemtoon word deur Schrage (1997:30).

32 Oor die kategorie van die performatiewe vorm vgl. Zumstein (1991:329-331). 
bestaan waarvan hy die dwaasheid besef, en deur hierdie versaking wat deur die evangelie van die kruis aan die gang gesit is, word die moontlikheid van 'n nuwe weg aan hom gebied.

Die leuse van hierdie nuwe pad is die woorde in Jeremia 9:22-23, wat Paulus aan die einde van sy kommentaar op die gemeenskap van Korinte plaas: "Dié wat roem, moet in die Here roem" (1 Kor. 1:31). Hy wat sy afstand hou van wysheid en godsdienstigheid en afsien daarvan om redding op sy eie te bewerkstellig, sal opgeroep word om sy vertroue op die enigste en blywende fondament te plaas, in God. ${ }^{33}$ Hy word opgeroep om alles van God te ontvang, en dit - metafories gestel - is by die voet van die kruis: Die gelowige gee homself oor aan die beslissende impetus van die kruis en aanvaar dat hy sy geloof binne die eindigheid van die geskiedenis lewe.

Die apostel se eie lewe is die paradigma van hierdie breuk. ${ }^{34} \mathrm{Op}$ sy pad na Damaskus en gekonfronteer deur die visioen van die opgestane gekruisigde Christus, moes Paulus sy godsdienstige ideaal van volmaaktheid prysgee; hy moes die ineenstorting van sy sekerhede aanvaar en breek met alles wat sy lewe voorbeeldig en ongetwyfeld suksesvol gemaak het ten einde sy geloof alleenlik op die persoon van die gekruisigde Christus te rig, om uitsluitlik deur sy genade te lewe en te aanvaar dat hy 'n apostel vol "swakheid ... vrees en bewing" is (1 Kor. 2:3). Presies in hierdie situasie van swakheid hoor hy die woorde: "My genade is vir jou genoeg, want my krag word in swakheid volbring” (2 Kor. 12:9).

\section{Gevolgtrekking}

Laat ek terugkeer na die vraag wat ek aan die einde van my inleiding gevra het. ${ }^{35}$ Wat is die strukturerende beginsel van Paulus se teologie? Kan 'n interne koherensie in die apostel se briewe gevind word wat die verskillende situasies waarvoor Paulus te staan kom en die verskillende vraagstukke waaroor hy praat, verbind? Met ander woorde: Wat is die sentrale teologiese

33 Oor die Pauliniese konsepte van om te roem en te vertrou, vgl. Bultmann (1938:648650).

34 Dietzfelbinger (1989:43-84) toon oortuigend aan waarom die Damakus-gebeure die beginpunt van Paulus se teologie is. Dit is van toepassing selfs hoewel die volle belangrikheid van die bekering eers na vore kom in die hervertellings wat Paulus self doen.

35 Vgl. 1 van hierdie artikel. 
verklaring waarop die Pauliniese diskoers in geheel gebaseer is en waarom dit georganiseer is? ${ }^{36}$

Vier opmerkings moet geformuleer word om hierdie vraag te beantwoord.

1. Paulus is nie 'n individualistiese charismatiese gelowige, wat buite die kerk van die tyd om optree as gevolg van 'n geloof gegrond bloot op 'n persoonlike openbaring nie. Hy behoort eerder aan een van die belangrikste Christelike gemeenskappe van die eerste helfte van die eerste eeu - die gemeenskap van Antiochië aan die Orontes; en hy integreer homself in een van die belangrikste strominge van die vroeë Christendom, nl. die kerugmatiese stroming, waarvan hy die fundamentele stellings aangeneem en gedeel het, en dit was om die evangelie te konsentreer op die dood en opstanding van Christus, en om die soteriologiese belangrikheid van die dood aan die kruis in verskillende interpretasies te beklemtoon. ${ }^{37}$

2. Paulus is nie slegs die verteenwoordiger van die tradisie nie, maar ook die interpreteerder daarvan. In die briewe aan die Korintiërs word sy teologiese kreatiwiteit uitgedruk in die sogenaamde "teologie van die kruis". Deur 'n nuwe taal te kies, verander die apostel die kruis in die hermeneutiese beginsel wat toelaat dat die werklikheid in die geheel polemies vertolk kan word.

3. Derhalwe moet die deurslaggewende vraag gevra word, naamlik of die teologie van die kruis, wat beslis die outonome werk van die apostel is, slegs 'n deel van sy werk bepaal, naamlik die Korintiese korrespondensie. Dit sou beteken dat dit onlosmaaklik geassosieer word met die krisis wat die kerk daardie tyd geskud het. In hierdie geval sou die apostel se werk uit twee teologiese hoofasse bestaan: die teologie van die kruis, wat in die twee briewe aan die Korintiërs ontwikkel is ${ }^{38}$, en die leerstelling van regverdigmaking, wat struktuur verleen aan die briewe aan die Galasiërs, die Filippense en die Romeine. So 'n digotomie sou egter te staan kom voor die probleem van eenheid en koherensie in die Pauliniese lering.

36 Die vraag oor die eenheid en koherensie van Paulus se teologie is die onderwerp van 'n heftige debat. Vgl. bv. Dunn (1998:1-26); Stuhlmacher (1992:234-252).

37 Oor die kerugmatiese stroming en die tradisie van Antiogië, vgl. Becker (1989:107-119); Hengel en Schwemer (1998).

38 Becker (198:235-254), sowel as Schrage (1974:164-165) het ondubbelsinnig aangetoon dat 2 Korintiërs deur die teologie van die kruis bepaal word. 
Daar is egter geen rede om hierdie twee hoofasse teenoor mekaar te stel nie. Aan die een kant kom die taal van die teologie van die kruis nie net in die Korintiese briewe voor nie, maar ook in die briewe aan die Galasiërs en Filippense; aan die ander kant - en dit is sekerlik die deurslaggewende argument - toon die teologie van die kruis soos dit in die briewe aan die Korintiërs ontwikkel is, en die leerstelling van regverdigmaking deur geloof sonder die werke van die Wet soos dit in die briewe aan die Galasiërs, Filippense en Romeine voorkom, dieselfde teologiese struktuur. Christoph $\mathrm{Senft}^{39}$ sê tereg: "A l'abolition de la Loi par I'Evangile de la grâce correspond la destitution de la sagesse; à la justification de l'impie, l'élection de ce qui n'existe pas $(1,28)$; à la foi la glorification dans le Seigneur $(1,32)$ ". Hoe moet hierdie bevinding vertolk word? ${ }^{40}$ Die teologie van die kruis soos dit in die Korintiese briewe na vore kom, is nie die enigste moontlike ontwikkeling van die boodskap van die kruis nie; die leerstelling van regverdigmaking bied ook 'n juiste interpretasie van die boodskap van die kruis, hoewel dit onafhanklik van die terminologie van die teologie van die kruis geformuleer word. Derhalwe kan ons tereg tot die gevolgtrekking kom, aan die een kant, dat die boodskap van die kruis die fundamentele beginsel van die Pauliniese teologie verteenwoordig, en, aan die ander kant, dat hierdie fundamentele beginsel ontwikkel is in die teologie van die kruis en die leerstelling van regverdigmaking.

4. Ten slotte moet kommentaar gelewer word op die tese, soos deur sommige interpreteerders gehuldig, dat die teologie van die kruis ontstaan het uit die krisis met die entoesiaste in Korinte, terwyl die leerstelling van die regverdigmaking die spesifieke antwoord was op die nomistiese krisis wat die gemeenskappe in Galasië en Filippi verdeel het. ${ }^{41}$ Volgens hierdie hipotese was Paulus se teologie 'n suiwer reaktiewe teologie. Ten einde onmiddellike konflikte op te los, sou die apostel teologiese ontwerpe vir die heersende omstandighede geskets het. Hierdie tese is geldig in sover Paulus se teologie uiteindelik altyd 'n situasie-spesifieke interpretasie

39 Senft (1990:42).

40 Vergelyk ten opsigte van hierdie vraag die skerpsinnige ontleding deur Haldimann (2002:23-25).

41 Die werke van E.P. Sanders is 'n voorbeeld van 'n "reaktiewe" konsep van Paulus se teologie: die onderwerp van regverdigmaking sou 'n spesifieke antwoord op die probleem van die sending na die heidene wees. 
van die evangelie is. ${ }^{42}$ Hierdie tese benodig egter 'n deurslaggewende komplement. Slegs omdat Paulus die hermeneutiese beginsel van die boodskap van die kruis erken het, wat'n duidelik afgebakende interpretasie van die werklikheid moontlik gemaak het, kon hy ook die vals leerstellings identifiseer en blootlê binne daardie gemeenskappe waarvoor hy pastoraal verantwoordelik was.

\section{Bibliografie}

Barth, G 1992. Der Tod Jesu im Verständnis des Neuen Testaments.

Neukirchen-Vluyn: Neukirchener Verlag.

Becker, J 1989. Paulus. Der Apostel der Völker. Tübingen: Mohr Siebeck.

Bornkamm, G 1969. Paulus. Stuttgart: Kohlhammer.

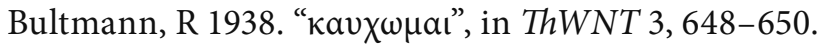

Bultmann, R 1949. Das Urchristentum im Rahmen der antiken Religionen.

Zurich: Artemis Verlag.

Bultmann, R 1965. “Anknüpfung und Widerspruch”, in idem (red.),

Glauben und Verstehen II Tübingen: Mohr Siebeck, 117-132.

Bultmann, R 1984. Theologie des Neuen Testaments, Tübingen: Mohr Siebeck.

Conzelmann, H et aI., 1967. Zur Bedeutung des Todes Jesu. Exegetische

Beiträge, Gütersloh: Gütersloher Verlag.

Conzelmann, H 1969. Der erste Brief an die Korinther. Göttingen:

Vandenhoeck \& Ruprecht.

Conzelmann, H 1974. Was glaubte die frühe Christenheit? in idem,

Theologie als Schriftauslegung. Aufsätze zum Neuen Testament,

München: Verlag CH Beck, 106-119; Conzelmann, H 1997. Grundriss

der Theologie des Neuen Testaments. Tübingen: Mohr Siebeck.

Cuvillier, E 2000. "Entre théologie de la croix et éthique de I’excès: une lecture de 1 Corinthiens 13" ETR 75, 349-362.

42 Soos verwoord deur Haldimann (2002:25). 
Dietzfelbinger, Ch 1989. Die Berufung des Paulus als Ursprung seiner Theologie. Neukirchen-Vluyn: Neukirchener Verlag.

Dubied, PL 1982. L'athéisme: une maladie spirituelle. Genève:Labor et Fides.

Dunn, JDG 1998. The Theology of Paul the Apostle. Grand Rapids: Eerdmans.

Goppelt, L 1976. Theologie des Neuen Testaments, Band 2: Vielfalt und Einheit des apostolischen Zeugnisses. Göttingen: Vandenhoeck \& Ruprecht.

Haldimann, K 2002. Kreuz - Wort vom Kreuz - Kreuzestheologie, in Kreuzestheologie im Neuen Testament, Dettwiler, A \& Zumstein, J (eds.), Tübingen: Mohr Siebeck, 1-25.

Hengel, M \& Schwemer, AM 1998. Paulus zwischen Damaskus und Antiochien. Tübingen: Mohr Siebeck.

Hübner, H 1987. Paulusforschung seit 1945. Ein kritische Literaturbericht, in ANRW 2.25.4, 2649-2840.

Käsemann, E 1969. “Die Heilsbedeutung des Todes Jesu bei Paulus”, in idem, Paulinische Perspektiven, Tübingen: Mohr Siebeck, 61-107.

Käsemann, E 1973. An die Römer. Tübingen: Mohr Siebeck.

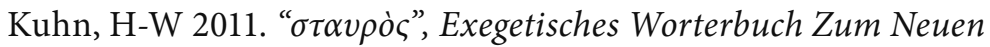
Testament III, Balz, H \& Schneider G (eds.), Stuttgart: Kohlhammer, 639-646.

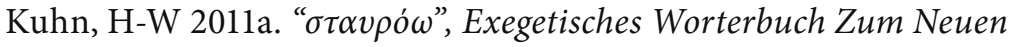
Testament III, Balz, H \& Schneider G (eds.), Stuttgart: Kohlhammer, 646-650.

Lohse, E 1996. Paulus. Eine Biograplie. München: Verlag C.H. Beck.

Luz, U 1974. “Theologia crucis als Mitte der Theologie im Neuen Testament”, EvTh 34,116-141.

Merk, O 1988. Paulus-Forschung 1936-1985, ThR 53, 1-81.

Rengstorf, KH (red.) 1982. Das Paulusbild in der neueren deutschen Forschung, Darmstadt: Wissenschaftliche Buchgesellschaft, 1-97. 
Sanders, EP 1995. Paulus. Eine Einführung. Stuttgart: Kohlhammer.

Schrage, W 1974. Kreuz und Eschaton. Die Peristasenkataloge als

Merkmale paulinischer theologia crucis und Eschatologie, EvTh 34: 141-175.

Schrage, W 1991. Der erste Brief an die Korinther. Neukirchen:

Neukirchener Verlag.

Schrage, W 1997. Der gekreuzigte und auferweckte Herr, ZThK 94, 25-38.

Schrage, W 2001. Der erste Brief an die Korinther 1 Kor. 15:1-16, 24.

Neukirchen-Vluyn: Neukirchnener Verlag.

Stendhal, K 1978. Der Jude Paulus und wir Heiden. München: Verlag CH Beck.

Senft, C 1990. La première Epître de Saint Paul aux Corinthiens. Genève: Labor et Fides.

Strecker, G 1996. Theologie des Neuen Testaments Berlyn: De Gruyter. Stuhlmacher, P 1992. Biblische Theologie des Neuen Testaments. Band I: Grundlegung: Von Jesus zu Paulus. Göttingen: Vandenhoeck \& Ruprecht.

Vouga, F 2001. Une théologie du Nouveau Testament. Genève: Labor et Fides.

Weder, H 1981. Das Kreuz Jesu bei Paulus. Ein Versuch, über den Geschichtsbezug des christlichen Glaubens nachzudenken. Göttingen: Vandenhoeck \& Ruprecht, 125-137.

Wengst, K 1972. Christologische Formeln und Lieder des Urchristentums. Gütersloh: Gütersloher Verlag.

Zumstein, J 2000 "Theologie als Credoauslegung: Paulus und die urchristlichen Bekenntnisse", in P Bühler \& E Campi (reds.), Freiheit im Bekenntnis. Das Glaubensbekenntnis der Kirche in theologischer Perspektive Zürich: Pano Verlag, 93-108.

Zumstein, J 1991. "Jésus et les paraboles", in idem, Miettes exégétiques Geneve: Labor et Fides, 319-335. 